\title{
Penyimpangan Sosial Human Trafficking
}

\author{
Riza Rahmawati \\ Darman Manda \\ Universitas Muhammadiyah Makassar \\ darmanmanda1965@gmail.com \\ Rosleny Babo \\ Universitas Muhammadiyah Makassar \\ roslenybabo@unismuh.ac.id
}

\begin{abstract}
ABSTRAK
Penelitian yang dilaksanakan merupakan penelitian sosial budaya yang jenis penelitian yang digunakan adalah metode penelitian deskriptif dengan pendekatan kualitatif. Teknik analisis data yang digunakan teknik analisis secara kualitatif dengan menggambarkan secara utuh dan jelas. Penelitian ini bertujuan untuk mengetahui faktor yang melatarbelakangi terjadinya human trafficking, bentuk dari human trafficking dan peran dari pemerintah dalam menanggulangi terjadinya human traffiking yang ada di Kota Makassar. Dari hasil penelitian menunjukkan bahwa faktor yang melatarbelakangi terjadinya human trafficking dikarenakan kebutuhan ekonomi yang mendesak, baik dari korban maupun dari pelaku semuanya beralasan dikarenakan oleh kebutuhan ekonomi dan faktor yang lainnya juga dikarenakan oleh lingkungan dan teman bergaul dari orang yang bersangkutan. Adapun bentuk dari human trafficking itu sendiri adalah yang bersangkutan atau korban dijadikan sebagai PSK oleh pelaku dan hasil dari dengan menjadikan korban PSK sepenuhnya diambil oleh si pelaku. Dan peran dari pemerintah sendiri dalam menanggulangi terjadinya human trafficking itu dengan melakukan sosialisasi dan seminar-semina kepada masyarakat, tempat-tempat hiburan dan hotel-hotel yang berada disekitar pusat hiburan, dalam hal ini pemerintah bekerjasama dengan pihak kepolisian dan Lembaga-lembaga Sosial.
\end{abstract}

Kata Kunci : Penyimpangan Sosial, Masyarakat, Human Trafficking

\section{PENDAHULUAN}

Manusia sebagai makhluk sosial sepanjang sejarahnya akan senantiasa mengadakan interaksi-interaksi sosial dengan sesamanya dan dengan terjadinya interaksi ini, maka tumbuh dan terciptalah beberapa bentuk pola perilaku manusia di dalam masyarakat. Pola perilaku tersebut tentunya ada yang selaras dan ada pula yang menyimpang dari norma-norma atau kaedah-kaedah yang telah disepakati dan ditetapkan sebagai pedoman pergaulan hidup. Penyimpangan sosial atau perilaku menyimpang, sadar atau tidak sadar pernah kita alami atau kita lakukan. Penyimpangan sosial dapat terjadi dimanapun dan dilakukan oleh siapapun. Sejauh mana penyimpangan itu terjadi, besar atau kecil, dalam skala luas atau sempit tentu akan berakibat terganggunya keseimbangan kehidupan dalam masyarakat. Suatu perilaku dianggap menyimpang apabila tidak sesuai dengan nilai-nilai dan norma-norma sosial yang berlaku dalam 
masyarakat atau dengan kata lain penyimpangan (deviation) adalah segala macam pola perilaku yang tidak berhasil menyesuaikan diri (conformity) terhadap kehendak masyarakat. Ironisnya justru banyak masyarakat yang merasa bangga ketika melakukan penyimpangan salah satunya adalah perilaku human trafficking yang sudah masuk dalam kategori kejahatan manusia dikarenakan maraknya dan ironisnya perdagangan manusia itu.

Trafficking dalam pengertian sederhana merupakan sebuah bentuk perdagangan modern. Tidak hanya merampas hak asasi manusia sebagai korban, tetapi juga membuat mereka rentan terhadap penganiayaan atau siksaan fisik dan kerja paksa. Hal tersebut dapat menyebabkan trauma psikis, bahkan cacat dan kematian. Kasus trafficking dari tahun ke tahun semakin meningkat. Pengiriman tenaga kerja Indonesia ke luar negeri sering dijadikan modus kejahatan perdagangan manusia. Para korban perdagangan manusia ini biasanya masuk melalui jalur ilegal melalui para calo. Setiap tahun sedikitnya 450.000 warga Indonesia (70 persen adalah perempuan) diberangkatkan sebagai tenaga kerja ke luar negeri. Dari jumlah tersebut sekitar $46 \%$ terindikasi kuat menjadi korban tindak pidana perdagangan orang (hasil kajian Migrant Care Tahun 2009). Seperti yang terjadi di Kota Makassar, Sulawesi Selatan, kasus Human Trafficking sangatlah mengkhawatirkan. Kota Makassar bisa dikatakan sebagai daerah yang dimana kasus perdagangan manusianya tinggi. Dan Kota Makassar, Sulawesi Selatan menjadi urutan ke-11 dimana marak terjadinya human trafficking dengan jumlah kasus perdagangan manusia mencapai 62 orang. Salah satu daerah yang paling rawan ditemukan human trafficking di Kota Makassar tepatnya di wilayah Kecamatan Wajo. Wilayah tersebut merupakan jalur perhubungan laut dan disekitar wilayah tersebut terdapat Tempat Hiburan Malam (THM) dan juga terdapat penginapan atau hotel yang dijadikan akses jalur human trafficking. Dikarenakan di tempat tersebut banyak terdapat tempat hiburan malam (THM) maka para korban yang telah diperjualbelikan dipekerjakan ditempattempat hiburan tersebut. Dan yang anak-anak banyak yang dipekerjakan menjadi pengemis dan pengamen dan uang hasil mengemis dan mengamen diserahkan kepada orang yang telah mempekerjakan mereka, hal ini tentu merusak masa depan anak-anak tersebut, anak-anak yang seharusnya duduk di bangku sekolah malah dipekerjakan menjadi pengemis dan pengamen. Didasari berbagai hal yang terjadi, disadari bahwa dalam menangani komplektisitas permasalahan trafficking, tidak hanya peran pemerintahan daerah saja yang dibutuhkan namun dibutuhkan kerja sama dari semua pihak baik instansi yang bersangkutan, LSM/ORMAS, maupun masyarakat, hingga 
aparat penegak hukum yang langsung berhadapan dengan berbagai kasus perdagangan orang, diharapkan dapat mencegah atau setidaknya mengurangi terjadinya kejahatan perdagangan orang yang terjadi di masyarakat di Kota Makassar.

\section{LANDASAN TEORI}

M. Z Lawang (Setiadi 2011; 188), membatasi perilaku menyimpang meliputi semua tindakan yang menyimpang dari norma-norma yang berlaku dalam suatu sistem sosial dan menimbulkan usaha dari mereka yang berwenang dalam sistem itu untuk memperbaiki perilaku tersebut. J. Cohen (Setiadi 2011; 188) membatasi perilaku menyimpang sebagai setiap perilaku yang tidak berhasil menyesuaikan diri dengan kehendak masyarakat atau kelompok tertentu dalam masyarakat. B. Herton (Setiadi 2011; 188), perilaku menyimpang adalah setiap perilaku yang dinyatakan sebagai pelanggaran terhadap norma-norma kelompok atau masyarakat. Dari berbagai batasan tersebut dapat disimpulkan bahwa perilaku menyimpang pada dasarnya adalah semua perilaku manusia yang dilakukan baik secara individual maupun secara kelompok tidak sesuai dengan nilainilai dan norma-norma yang berlaku di dalam suatu kelompok tersebut. Paul Horton (Setiadi 2011; 194) mengemukakan ada enam ciri-ciri perilaku menyimpang diantaranya: Penyimpangan harus dapat didefenisikan, Penyimpangan bisa juga diterima bisa juga ditolak, Penyimpangan relatif dan penyimpangan mutlak, Penyimpangan terhadap budaya nyata dan budaya ideal, Terdapat norma-norma penghindaran, Penyimpangan sosial yang bersifat adaptif (penyesuaian). Penyimpangan sosial bisa juga di kategorikan sebagai patologi sosial yang berarti penyakit masyarakat/sosial atau merupakan segenap tingkah laku manusia yang dianggap tidak sesuai, melanggar norma-norma umum dan adat istiadat, atau tidak terintegrasi dengan tingkah laku umum, diantaranya yaitu: perjudian, korupsi, kriminologi, pelacuran, penyalahan narkotika dan obat-obat terlarang, perkelahian antar pelajar atau mahasiswa, homoseks dan alkoholisme. Adapun sebabsebab terjadinya perilaku menyimpang menurut Setiadi $(2011 ; 215)$ yaitu: sikap mental yang tidak sehat, ketidakharmonisan dalam keluarga, pelampiasan rasa kecewa, dorongan kebutuhan ekonomi, pengaruh lingkungan dan media massa, ketidaksanggupan menyerap norma, proses sosialisasi nilai-nilai subkultur menyimpang, kegagalan dalam proses sosialisasi, dan adanya ikatan sosial yang berlainan. Pengertian human trafficking adalah menurut Global Alliance Against Traffic in Woman (GAATW) mendefinisikan perdagangan (trafficking) sebagai semua usaha atau tindakan yang berkaitan dengan perekrutan, pembelian, penjualan, transfer, pengiriman, atau penerimaan seseorang 
dengan menggunakan penipuan atau tekanan, termasuk pengunaan ancaman kekerasan atau penyalahgunaan kekuasaan atau lilitan hutang dengan tujuan untuk menempatkan atau menahan orang tersebut, baik dibayar atau tidak, untuk kerja yang tidak diinginkan (domestik seksual atau reproduktif) dalam kerja paksa atau dalam kondisi perbudakan, dalam suatu lingkungan lain dari tempat dimana orang itu tinggal pada waktu penipuan, tekanan atau lilitan hutang pertama kali. Tidak ada satu pun yang merupakan sebab khusus terjadinya trafficking manusia di Indonesia. Trafficking disebabkan oleh keseluruhan hal yang terdiri dari bermacam-macam kondisi serta persoalan yang berbedabeda. Termasuk ke dalamnya adalah: kemiskinan, keinginan cepat kaya, pengaruh sosial budaya, kurangnya pencatatan kelahiran, korupsi dan lemahnya penegakan hukum, media massa, dan pendidikan minim dan tingkat buta huruf. Ada beberapa bentuk human trafficking yang terjadi pada perempuan dan anak-anak, yaitu: kerja paksa, pembantu rumah tangga, bentuk lain dari kerja migran, penari/penghibur, pengantin pesanan, beberapa bentuk buruh/pekerja anak, dan penjualan bayi.

Perdagangan orang, khususnya perempuan sebagai suatu bentuk tindak kejahatan yang kompleks, tentunya memerlukan upaya penanganan yang komprehensif dan terpadu. Tidak hanya dibutuhkan pengetahuan dan keahlian profesional, namun juga pengumpulan dan pertukaran informasi, kerjasama yang memadai baik sesama aparat penegak hukum seperti kepolisian, kejaksaan, hakim maupun dengan pihak-pihak lain yang terkait yaitu lembaga pemerintah (kementerian terkait) dan lembaga non pemerintah (LSM) baik lokal maupun internasional. Semua pihak bisa saling bertukar informasi dan keahlian profesi sesuai dengan kewenangan masing-masing dan kode etik instansi. Tidak hanya perihal pencegahan, namun juga penanganan kasus dan perlindungan korban semakin memberikan pembenaran bagi upaya pencegahan dan penanggulangan perdagangan perempuan secara terpadu. Hal ini bertujuan untuk memastikan agar korban mendapatkan hak atas perlindungan dalam hukum.

\section{METODE PENELITIAN}

Metode yang digunakan dalam penelitian ini adalah metode penelitian deskriptif dengan menggunakan pendekatan kualitatif. Lokasi penelitian ini adalah di Resor Pelabuhan Makassar dan Kecamatan Wajo Kota Makassar, Sulawesi Selatan. Waktu penelitian ini dimulai dari tanggal 10 Juli 2015 sampai dengan 10 September 2015. Objek penelitian adalah masyarakat yang berkaitan dengan kasus Human Trafficking yang ada di Kota Makassar. Sementara yang menjadi sumber informasi dalam penelitian adalah 
diantaranya dua dari Kepolisian Resort Pelabuhan Kota Makassar, satu dari orang tua korban,dan dari Camat di Kecamatan Wajo. Serta data dari pihak kepolisian Resor Pelabuhan Kota Makassar. Dalam penelitian ini, teknik pengumpulan data yang dilakukan dengan memanfaatkan beberapa media, diantaranya: Observasi, wawancara/interview dan dokumentasi.

\section{PEMBAHASAN}

\section{Faktor yang Melatarbelakangi Terjadinya Human Trafficking di Kota Makassar}

Faktor yang melatarbelakangi terjadinya human trafficking berdasarkan hasil penelitian dan wawancara yang telah dilakukan oleh peneliti adalah dikarenakan oleh beberapa faktor yaitu faktor ekonomi dan faktor lingkungan sosial dan teman-teman.

a. Faktor Ekonomi

Secara ekonomi kemiskinan dapat diartikan sebagai kekurangan sumber daya yang dapat digunakan untuk meningkatkan kesejahteraan masyarakat. Jika diartikan dengan pendapatan dan kebutuhan dasar maka kemiskinan dapat diukur secara langsung, yaitu ketika pendapatan masyarakat tidak dapat memenuhi kebutuhan dasar minimum maka orang ini dapat dikatakan miskin. Dalam hal ini kemiskinan ditentukan oleh keadaan tidak tercapainya kebutuhan dasar sesuai dengan kebutuhan saat ini. Sehingga pekerjaan yang cepat menghasilakn uang seperti seks komersial kemudian menjadi jalan alternatif yang mudah untuk mengatasi masalah pembiayaan hidup bagi sebagian masyarakat terutama perempuan dan anak-anak. Seks komersial ini dianggap sebagai pekerjan yang sangat mudah untuk mendapatkan sumber kehidupan. Merujuk pada kisah dari saudari $\mathrm{N}$, faktor ekonomi menjadi salah satu faktor sehingga dia terjerat dalam kasus perdagangan manusia karena saudari $\mathrm{N}$ membutuhkan uang untuk membeli peralatan tulis. Sehingga kemudian saudari N dipekerjakan menjadi seorang PSK oleh pelaku.

b. Faktor Lingkungan dan Teman-teman

Korban yang dalam kesehariannya sering bergabung dan berteman dengan teman-temannya yang pergaulannya sungguh diluar batas wajar bagi seorang siswa SMP, dan juga korban diperkenalkan oleh temannya sendiri kepada pelaku. Dan juga lingkungan sekitar korban merupakan lingkungan yang di mana anak-anak dibawah umur cara bergaulnya sudah diluar batas. Sehingga anak-anak disekitar lingkunganya ada yang sudah berhenti sekolah dan menjadi pengangguran. 


\section{Bentuk dari Human Trafficking yang Terjadi di Kota Makassar}

Bentuk-bentuk dari human trafficking itu sendiri banyak tergantung dari kasus yang diselidiki. Adapun berdasarkan hasil penelitian peneliti dan wawancara terhadap salah satu kasus human trafficking di Kota Makassar adalah si korban ditawarkan sebuah pekerjaan oleh temannya dengan iming-iming akan mendapatkan penghasilan yang banyak, diantaranya menjadi seorang PSK. Pekerja seks komersial merupakan seseorang yang menjual jasanya untuk melakukan hubungan seksual dan kemudian akan dibayar dengan uang. Selain sebagai PSK bagi anak-anak akan dijadikan sebagai pekerja anak dengan mempekerjaka anak-anak tersebut sebagai pemulung, pengemis dan pengamen dan hasilnya harus diserahkan kepada orang yang menjadi majikannya dan tentu hal ini membawa keuntungan bagi orang yang menjadikannya sebagai pengemis, pemulung maupun pengamen. Adapun pengertian dari pekerja anak-anak itu sendiri dapat diartikan sebagai anak-anak yang melakukan pekerjaan secara rutin untuk orangtuanya atau untuk orang lain yang membutuhkan sejumlah besar waktu, dengan menerima imbalan atau tidak. Menurut UU nomor 4 Tahun 1979 Tentang Kesejahteraan Anak, yang dimaksud dengan anak adalah seseorang yang berusia di bawah 21 tahun dan belum menikah, sedangkan menurut UU Nomor 23 Tahun 2002 tentang perlindungan anak, anak adalah seseorang yang belum berusia 18 tahun, termasuk anak yang masih dalam kandungan.

\section{Peran Pemerintah dalam Menanggulangi Terjadinya Human Trafficking}

Dari penelitian yang peneliti lakukan peranan dari pemerintah setempat dalam menanggulangi masalah human trafficking yang terjadinya disekitar lingkungannya yaitu dengan melakukan berbagai sosialisasi dan juga seminar-seminar dengan bekerja sama dengan pihak dari Kepolisian setempat maupun mengudang juga LSM-LSM dan juga bekerja sama dengan kantor Dinas Sosial, media cetak, media elektronik. Maksud sosialisasi dan seminar-seminar ini dilakukan agar masyarakat menyetahui Pasal 297 Kitab Undang-Undang Hukum Pidana menyatakan yang bahwa : "Memperdagangkan perempuan dan laki-laki yang belum dewasa, dihukum penjara paling lama enam tahun ". Dan Pasal 65 Undang-Undang Nomor 39 Tahun 1999 tentang Hak Asasi Manusia yang menyatakan bahwa : "Setiap anak berhak untuk memperoleh perlindungan dari kegiatan eksploitasi dan pelecehan seksual, penculikan, perdagangan anak, serta dari berbagai bentuk penyalahgunaan narkotika, psikotropika, dan zat adiktif lainnya”, memberikan perlindungan terhadap orang dari eksploitasi dan perbudakan manusia, menyelamatkan dan merehabilitasi korban perdagangan orang, dan juga untuk mengetahui dampak buruk dari kejahatan human trafficking, serta meningkatkan wawasan kita untuk menangani 
trafficking tersebut serta memberikan tindakan terhadap pelaku maupun pihak-pihak yang mendukung perdagangan orang. Mayarakat secara umum sangat rawan menjadi korban trafficking apabila tidak mempunyai bekal pengetahuan yang memadai tentang masalah ini. Untuk itulah, dilakukan sosialisasi secara massif untuk menyebarluaskan informasi tentang apa dan bagaimana praktek trafficking yang harus diwaspadai itu. Upaya sosialisasi ini adalah bagaian dari program yang telah disepakati bersama. Mereka perluh mendapatkan pengetahuan secara komprehensif tentang human trafficking ini.

\section{KESIMPULAN}

Setelah melakukan penelitian, maka peneliti dapat menyimpulkan beberapa kesimpulan untuk menjawab masalah yang diangkat dalam penelitian ini, kesimpulan yang dapat ditarik yaitu :

1. Faktor yang melatarbelakangi terjadi human trafficking di Kota Makassar khususnya di Kecamatan Wajo yang merupakan jalur perhubungan dan banyak terdapat tempat hiburan adalah di karenakan oleh faktor desakan ekonomi yang sangat tinggi dari orang yang melakukannya entah itu dari korban maupun pelaku alasannya keduanya sama dan juga dipengaruhi oleh faktor teman dan lingkungan pergaulannya seharihari.

2. Bentuk-bentuk dari human trafficking yang ada di Kota Makassar adalah korban yang wanita biasanya akan dijadikan sebagai PSK atau wanita penghibur dan anak-anak akan dijadikan sebagai buruh kasar.

3. Adapun peranan pemerintah khusunya pihak pemerintah dari Kecamatan Wajo yang di mana di wilayah Kecamatan Wajo ini banyak terdapat tempat hiburan dan hotelhotel dikarenakan wilayah Kecamatan Wajo adalah wilayah yang terdapat pelabuhan jalur keluar masuk masyarakat antar kota dan adapaun upaya dari pemerintah setempat dalam menanggulangi masalah human trafficking, sejauh ini sudah semaksimal mungkin dengan cara melakukan sosialisasi dengan melakukan seminar-seminar di hotel-hotel yang terdapat di wilayahnya dengan bekerjasama dengan pihak kepolisian di wilayahnya yaitu Resor Pelabuhan Makassar juga dan juga bekerjasama dengan Dinas Sosial dan LSM-LSM, selain itu uapaya yang dilakukan juga adalah dengan sering melakukan razia ke tepat-tempat hiburan yang ada dengan bekerjasama dengan Polisi Pamong Praja. 


\section{DAFTAR PUSTAKA}

Ardiansyah Ibrahim, Imam. (2013). Tinjauan Viktimologis Terhadap Kejahatan Perdagangan Orang (Human Trafficking) Di Kota Bandung. Skripsi tidak diterbitkan. Makassar. Unhas Makassar.

Atmasasmita, Romli. (1992). Teori dan Kapita Selekta Kriminologi. Bandung: PT. Eresco.

FKIP Unismuh Makassar. (2012). Pedoman Penulisan Skripsi. Makassar : Panrita Press.

Kartono, Kartini. (2013). Patologi Sosial. Jakarta : PT RajaGrafindo Persada.

Narwoko, J. Dwi dan Suyanto, Bagong. 2004. Sosiologi Teks Pengantar dan Terapan. Surabaya : Kencana.

Nurdiana, (2012). Skripsi. Makassar : Fakultas Ilmu Sosial Universitas Negeri Makassar.

Priyanto, Anang. (2012). Kriminologi. Yogyakarta : Badan Penerbit Ombak (Anggota IKAPI).

Saepudin Jahar, Asep dan Banadjid. (2013). Sosiologi Sebuah Pengantar. Jakarta : Laboratorium Sosiologi Agama.

Scaefer, Richard T. 2001. Sosiology. New York: McGraw Hill.

Setiadi, Elly. 2011. Pengantar Sosiologi Pemahaman Fakta dan Gejala Permasalahan Sosial; Teori, Aplikasi, dan Pemecahannya. Jakarta : Kencana.

Soekanto, Soejorno. 1984. Sosiologi Suatu Pengantar, cetakan ke-28. Jakarta: Yayasan Obor Indonesia.

Sugiyono. 2014. Metode Penelitian Kuantitatif, Kualitatif, dan $R \& D$. Bandung :

ALFABETA cv.

Okviany, Lilies. 2012. Perdagangan Anak dan Perempuan, (Online), http://intelektualhukum.wordpress.com/2010/01/14/perdagangan-trafficking-anakdan-perempuan, diakses 18 April 2015. 